\title{
Effect of high doses of L-ascorbic acid on the antioxidative/oxidative state in the rats
}

\author{
T. Niemiec ${ }^{1,3}$, E. Sawosz ${ }^{1}$ and A. Chwalibog ${ }^{2}$ \\ ${ }^{1}$ Warsaw Agricultural University, \\ Department of Animal Nutrition and Feed Science \\ Ciszewskiego 8, 02-786 Warszawa, Poland \\ ${ }^{2}$ The Royal Veterinary and Agricultural University, \\ Department of Animal and Veterinary Basic Sciences \\ Bülowsvej 13, Frederiksberg C, Denmark
}

\begin{abstract}
The objective of this study was to determine the effects of mega-doses of vitamin $\mathrm{C}(0.3,0.6$ and $0.9 \%$ of diet) as a dietary supplement for rats on selected indices of the antioxidative/oxidative state in 40 growing Wistar rats $(4 \times 10)$. It was found that L-ascorbic acid and Total Antioxidative State (TAS) in plasma did not increase with increasing vitamin $\mathrm{C}$ supply. The results indicate that high doses of L-ascorbic acid ( 0.3 and 0.9 but not $0.6 \%)$ increased the concentration of this antioxidant in plasma. Supplementation of vitamin C above $0.3 \%$ to the diets had pro-oxidative effects on lipid structures, while application of $0.9 \%$ promoted oxidative degradation of rat livers.
\end{abstract}

KEY WORDS: ascorbic acid, antioxidative/oxidative state, rats

\section{INTRODUCTION}

Ascorbic acid is an important micromolecule for animals and humans, as it is involved in many biological mechanisms. It is a powerful antioxidant acting both directly via scavenging of reactive oxygen species and indirectly through regeneration of other antioxidant systems. Paradoxically, under certain conditions (low concentration, presence of metal ions) it can exert a pro-oxidant effect, increasing oxidative damage of lipids, proteins and DNA (Auroma et al., 1999). The objective of this study was to determine effects of high doses of vitamin $\mathrm{C}$ on antioxidative/oxidative indicators of redox homeostasis in growing rats.

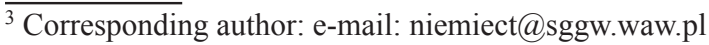




\section{MATERIAL AND METHODS}

Forty growing male Wistar rats (235 g body weight) were divided into 4 groups $\times 10$ animals and were kept in individual cages for 41 days under standard conditions: temperature $22^{\circ} \mathrm{C}$, humidity $50-70 \%$, light/dark $12 / 12 \mathrm{~h}$. The rats received a semi-purified mixture, containing (in \%): maize starch, 62, casein, 14, saccharose, 10, cellulose, 5, rapeseed oil, 5, mineral and vitamin mix., 3.7, L-cystine, 0.2 and chloride choline, 0.1 . The mixture was supplemented with 0 (control group), $0.3,0.6$ and $0.9 \%$ of L-ascorbic acid.

Vitamin C, mineral and vitamin mixtures were obtained from ICN Biomedicals. At the end of the experiment the rats were fasted for $12 \mathrm{~h}$, sedated by intramuscular ketamine at a dose of $50 \mathrm{mg} / \mathrm{kg}$ body weight. Blood was sampled from the heart into heparinized tubes, cooled to $4^{\circ} \mathrm{C}$ and analysed. The animals were euthanized by ketamine overdose and then the livers were removed. Determination of ascorbate in plasma was performed by HPLC-UV detection. Total Antioxidative State (TAS) in plasma, activities of superoxide dismutase (SOD) and glutathione peroxidase (GPx) in the red blood cells were analysed by Randox Laboratories Ltd. Kits in a COBAS FARA II analyser. 8-oxo-2'-deoxyguanosine (8-oxo-dG) in livers was determined using HPLC with an electrochemical and UV detector. Thiobarbituric acid reactive substances (TBARS) were measured by a colorimetric method using 1.2.3.3.-tetraethoxypropane (TEP) as the standard.

The results were analysed by monofactorial ANOVA and Duncan's multiple range test, using the Statgraphic 4.1 Plus software package.

\section{RESULTS AND DISCUSSION}

The concentration of $\mathrm{C}$ vitamin in blood serum of rats receiving diets with 0.3 and $0.9 \%$ of $\mathrm{C}$ vitamin was higher than in the control and $0.6 \%$ groups (Table 1). It has been demonstrated that $\mathrm{C}$ vitamin stimulates antioxidant potential (El-Missiry, 1999) and decreases the concentration of the final products of the peroxidation of cell structures (Bano and Parihar, 1997; Chen et al., 2000). The addition to a diet of $0.3 \%$ of $\mathrm{C}$ vitamin increased the concentration of TAS in plasma, which is in agreement with measurements on growing pigs (Sawosz, 1999). It may be considered that the addition of $0.3 \%$ of $\mathrm{C}$ vitamin to a diet can influence a reductive potential of plasma. Furthermore, it can be expected that the addition of $0.6 \%$ of $\mathrm{C}$ vitamin can activate a feedback mechanism of ascorbic acid biosynthesis in rat hepatocytes (Banhegyi et al., 1997) causing decreasing concentration of $\mathrm{C}$ vitamin and a lower level of TAS in serum. However, the elevation of $\mathrm{C}$ vitamin up to $0.9 \%$ did not increase the TAS level. 
Table 1. Concentration of ascorbic acid, TAS, TBARS in the plasma; SOD, GPx activity in red blood cells and concentration of 8-oxo-2'-deoxyguanosine in the liver of rats

\begin{tabular}{|c|c|c|c|c|c|c|}
\hline \multirow{2}{*}{ Parameter } & & \multicolumn{3}{|c|}{ Dietary ascorbate, $\%$} & \multirow{2}{*}{ SEM } & \multirow{2}{*}{$\mathrm{P}$} \\
\hline & & 0.3 & 0.6 & 0.9 & & \\
\hline Ascorbic acid, $\mu \mathrm{mol} / \mathrm{L}$ & $26.223^{\mathrm{a}}$ & $35.952^{\mathrm{b}}$ & $30.429^{\mathrm{a}}$ & $53.530^{c}$ & 2.905 & $<0.001$ \\
\hline $\mathrm{TAS}^{1}, \mathrm{mmol} / \mathrm{L}$ & $0.610^{\mathrm{b}}$ & $0.816^{\mathrm{c}}$ & $0.482^{\mathrm{a}}$ & $0.658^{\mathrm{b}}$ & 0.034 & $<0.001$ \\
\hline $\mathrm{SOD}^{2}, \mathrm{U} / \mathrm{gHb}$ & 1947.72 & 1619.74 & 2006.52 & 1833.32 & 312.2 & NS \\
\hline $\mathrm{GPx}^{3}, \mathrm{U} / \mathrm{gHb}$ & 20.96 & 18.93 & 20.09 & 22.70 & 1.337 & NS \\
\hline $\mathrm{TBARS}^{4}, \mu \mathrm{mol} / \mathrm{L}$ & $2.838^{\mathrm{a}}$ & $3.245^{\mathrm{b}}$ & $3.439^{\mathrm{b}}$ & $3.226^{\mathrm{b}}$ & 0.081 & $<0.001$ \\
\hline $\begin{array}{l}\text { 8-oxo-2'-deoxy guanosine, } \\
\text { 8-oxodG } / 10^{6} \mathrm{dG}\end{array}$ & $4.386^{\mathrm{a}}$ & $4.898^{\mathrm{ab}}$ & $4.040^{\mathrm{a}}$ & $5.888^{\mathrm{b}}$ & 0.343 & 0.009 \\
\hline
\end{tabular}

An increase in the products of lipid peroxidation, evaluated on the basis of TBARS level, may suggest that $C$ vitamin added above $0.3 \%$ of a diet promotes oxidative lipid degradation (Table 1). Furthermore, Nyssonen et al. (1997) demonstrated that supplementing $3 \mathrm{~g} \mathrm{C}$ vitamin $/ \mathrm{kg}$ body weight for smokers increased the concentration of TBARS in plasma. In the present investigation, $\mathrm{C}$ vitamin was administrated to animals that were not being stressed and were able to synthesize it and, consequently, high doses of $\mathrm{C}$ vitamin could tip the redox balance to the side of oxidative reactions.

Lipid peroxidation may be activated by numerous reactive oxygen species in contrast to DNA oxidation, which is less prone to reactive oxygen species. The antioxidative defence system effectively protected DNA from oxidation when 0.3 and $0.6 \% \mathrm{C}$ vitamin were added (Table 1 ). However, supplementation of the diet with $0.9 \%$ led to oxidative DNA damage in the liver of rats.

The pro-oxidative capabilities of ascorbic acid have been demonstrated by measuring the content of 8-oxo-2'-deoxyguanosine (Podmore et al., 1998). A DNA adduct, 8-oxo-2-deoxyguanosine, is formed as the result of guanine being attacked by hydroxyl radicals or singlet oxygen. Vitamin $\mathrm{C}$ not only scavenges free radicals, but also reduces redox-active transition metal ions $(\mathrm{Fe}, \mathrm{Cu})$ and can be involved in generation of hydroxyl radicals via the Fenton reaction in vitro (Halliwell, 1999).

Vitamin $\mathrm{C}$ is thus a very active and rapidly penetrating compound, and when administrated at high doses may promote synthesis and generation of carcinogenic substances -TBARS and DNA adducts.

\section{CONCLUSIONS}

High doses of L-ascorbic acid $(0.3,0.6$ and $0.9 \%)$ in diets for rats increased the level of final products of lipid peroxidation. Although supplementation of $0.3 \%$ 
of $\mathrm{C}$ vitamin stimulated the total antioxidant state in serum, the diet with $0.9 \%$ caused oxidative degradation of DNA in the liver of rats.

\section{REFERENCES}

Auroma O.I., Halliwell B., Gajewski E., Dizdaroglu M., 1991. Copper ion-dependent damage to the bases in DNA in the presence of hydrogen peroxide. Biochem. J. 273, 601-604

Banhegyi G., Braun L., Csala M., Puskas F., Mandl J., 1997. Ascorbate metabolism and its regulation in animals. Free Radical Biol. Med. 23, 793-803

Bano S., Parihar M.S., 1997. Reduction of lipid peroxidation in different brain regions by a combination of alfa-tocoferol and ascorbic acid. J. Neural Transm. 104, 1277-1286

Chen K., Suh J., Carr A.C., Morrow J.D., Zeind J., Frei B., 2000. Vitamin C suppresses oxidative lipid damage in vivo even in the presence of iron overload. Amer. J. Physiol. - Endocrinol. Met. 279, E1406-E1412

El-Missiry M.A., 1999. Enhanced testicular antioxidant system by ascorbic acid in alloxan diabetic rats. Comp. Biochem. Physiol. Pt. C 124, 233-237

Halliwell B., 1999. Vitamin C: poison, prophylactic or panacea? Trends Biochem. Sci. 24, 255-259

Nyssonen K., Poulsen H.E., Hayn M., Agerbo P., Porkkala-Sarataho E., Kaikkonen J., Salonen R., Salonen J.T. 1997. Effect of supplementation of smoking men with plain or slow release ascorbic acid on lipoprotein oxidation. Eur. J. Clin. Nutr. 51, 154-163

Podmore I.D., Griffiths H.R., Herbert K.E., Mistry N., Mistry P., Lunec J., 1998. Vitamin C exhibits pro-oxidant properties. Nature 392, 559

Sawosz E., 1999. Influence of the diet enriched with polyunsaturated fatty acids, $\alpha$-tocopherol acetate and sodium ascorbinate on fatty acids composition in the muscle of growing pigs and rats. Warsaw Agricultural University Press, Warsaw, pp. 68

\section{STRESZCZENIE}

\section{Wpływ megadawek kwasu L-askorbinowego na stan antyoksydacyjno/oksydacyjny u szczurów}

Celem pracy było określenie wpływu megadawek witaminy $\mathrm{C}$, podawanych w ilościach 0,$3 ; 0,6$ i $0,9 \%$ mieszanki, na stan antyoksydacyjno/oksydacyjny szczurów. Badania przeprowadzono na 40 szczurach Wistar $(4 \times 10$ sztuk). Stwierdzono, że poziom kwasu L-askorbinowego oraz całkowity potencjał antyoksydacyjny (TAS) w osoczu nie zwiększał się proporcjonalnie do ilości dodawanej do mieszanki witaminy C. Dodatek kwasu L-askorbinowego do diety $(0,3$ i $0,9 \%$ vs 0,0 i $0,6 \%)$ spowodował zwiększenie jego stężenia w osoczu szczurów. Dodatek do diety $0,3 \%$ witaminy $C$ działał prooksydacyjnie w stosunku do struktur lipidowych organizmu, a zastosowanie witaminy $\mathrm{C}$ w ilości $0,9 \%$ wpłynęło na oksydacyjną degradację DNA wątroby szczurów. 